\title{
Eilert Sundt som selvmordsforsker
}

Ved Mauritz Sundt Mortensen

SUICIDOLOGI 1998, ̊̊RG. 3, NR. 1

Blant de mange emner og problemer som samfunnsforskeren Eilert Sundt (1817-75) undersøkte, analyserte og beskrev, var også selvmord. Dersom hans omfattende sosiologiske arbeider var blitt publisert på et av de store verdensspråkene, ville han utvilsomt ha rangert på linje med andre av sosiologiens pionerer.

Disse var forst og fremst den franske filosofen Auguste Comte (1789-1857) som ga faget dets navn i 1838(?), og sosialdarwinisten Herbert Spencer (1820. 1903) i England, senere franskmannen Émile Durkheim (1858-1917) og den tyske jurist og historiker Max Weber (1864-1920), samt amerikaneren Charles Horton Cooley (1864-1929). Mens flere av de nevnte må betegnes som "grublere", markerer Sundt seg først og fremst som grunnleggeren av den nitide empiriske metode. Ikke bare samlet han sine data ved personlige observasjoner og intervjuer for senere å bearbeide dem til statistiske oversikter. Han ville forstå innenfra de emnene han undersøkte, analyserte og deretter fremla og forklarte for sine lesere. Og han la stor vekt på å få frem betydningen av de data han fant, og sammenhengene mellom dem.

\section{Til fots}

Sundt som ble teolog i 1846 med beste karakter og anbefaling, var påsatt til å bli landets første professor i kirkehistorie og leve et sorgløst liv med tørre føtter ved Universitetet i Christiania. Men skjebnen ville det annerledes. Han hadde ekstrajobb som religionslærer ved Christiania Tugthus, og der møtte han noen tatere som vakte hans interesse. Dette førte ham over i et liv som forsker, fø̆st på omstreifernes liv, senere på de fattiges kår, og til sist med fokus på hele folkets liv og virke.

Med ettårige stipendier fra Stortinget gikk han til fots landet rundt og intervjuet vanlige mennesker. Resultatene av sommerhalvårets datainnsamling bearbeidet han om vinteren. Han satt ved et rundt spisebord i familiens treroms leilighet, og skrev med penn og blekk i lyset fra stearinlys, med fire-fem smårollinger omkring seg. I 1975 - på hundreårsdagen for hans død - ble et utvalg av hans skrifter utgitt i 11 bind på til sammen over 3200 sider på Gyldendal.
Emnene var utrolig varierte, nysgjerrigheten uten grenser, $\mathrm{g} g$ hans unders $\varnothing$ kelser til dels nærgående. I tillegg til sine egne observasjoner og opptegnelser fikk Sundt anledning til å innhente data fra sogneprestenes kirkebøker og årlige rapporter. (Statistisk sentralbyrå ble opprettet først i 1876.) Slik fikk han nøyaktige oppgaver over en lang rekke sosiale forhold, bl. a. om fødte og døde, samt årsaker til ulykker på land og sjø.

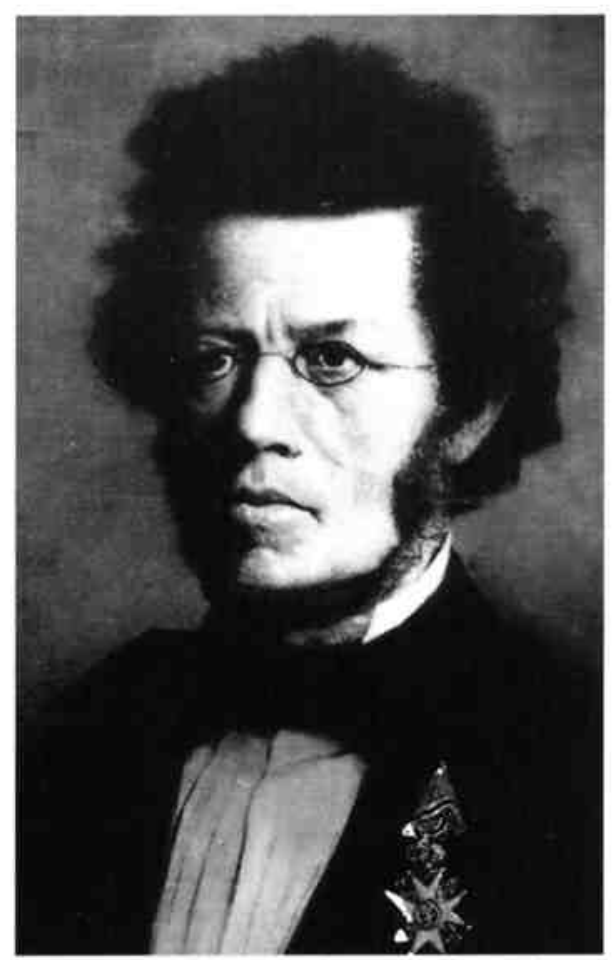

Eilert Sundt ca 1870, maleri av Knud Bergslien

Eilert Sundt (1817-75), yngst av 13 barn, vokste opp $i$ Farsund, avla eksamen ved Latinskolen $i$ Stavanger, var formann $i$ Studentersamfundet og holdt tale ved Henrik Wergelands båre $i$ Vår Frelsers Kirke, ble cand. theol. $i$ 1846, var larer i Christiania, stipendiat $i$ kirkehistorie, deretter samfunnsforsker 1850-70, samtidig redaktør av bladet "Folkevennen", og sogneprest på Eidsvold 1870-75.

\section{Respekt for mennesker}

Typisk for Eilert Sundt var den store respekt han hadde for de mennesker han møtte. Han hadde stor tro på menneskelig fornuft, og resonnerte som så at menneskene til enhver tid gjør det de anser som mest fornuftig under de gjeldende forhold. Så snart de blir tilført ny kunnskap, og nye hjelpemidler blir gjort tilgjengelige, vil folk søke å forbedre sine levekår. Dette har vel i ettertid stort sett vist seg å stemme.

Etter 20 år mistet Sundt sitt årlige stipendium etter en iherdig hets mot hans forskning fra bl. a. datidens leger, og en opprivende debatt i Stortinget. Han ble tvunget til å søke stilling som sogneprest. Han fikk Eidsvold. Selv om han er åpenlyst skuffet, avslutter Eilert Sundt forordet i sin siste bok slik:

"For mig selv tager jeg den erindring med, at det er sjelden, en forsker og forfatter har Nationalforsamlingen saa meget at takke for som jeg, og naar jeg byder og giver denne bog, hwori jo en ikke ringe del af mit liv er lagt, saa er det en ytring av den takknemlighedens stemning, som maa folge mig til min grav."

På ettersommeren 1875 døde han i en alder av bare 58 år.

\section{Selvmord}

Særlig grundig gikk Sundt til verks i sine studier av "dødeligheten" (bind nr. 2 av hans verker), hvor selvmord inngår i undergruppen "voldsom død". Her heter det bl. a (s. $130 \mathrm{ff})$ :

"Samme forunderlige, ja rystende regelmessighed finde vi også ved betragtningen af selumordet, denne besynderlig dunkle side af det menneskelige liv.

Selvmordets gåde er ikke forklaret med den sætning, at det er en syndig gieming. Thi for det forste udfores en storre eller mindre del af de forefaldende selvmord i en tilstand af vildelse, hvor det ikke langer er tilregnelighed; for det andet er 
der tusinder, som ikke alene lide tungt under næringssorg og hjertesorg og selvbebreidelse og sygdom, men som også hengive sig til mishåb og fortvivlelse det, som her er det egentlige syndige -, uden at dette mishåb og denne fortvivlelse leder til selvmord. Selvmordets gåde er heller ikke forklaret med den sætning, at det, udfort med full bevidsthed, er en sådan særegen syndig gierning, som udelukker habet om syndsforlatelse.

Thi efterat den ulykkelige har styrtet sig $u$ fra broen, og forend han hvirvles hen af fossen, $i$ sekunden, kan Guds and have grebet mennesket, og angeren $k a n$ have sukket og troen have vendt sig til ham, som sagde til røveren på korset: Idag skal du være med mig $i$ paradiset. En sikker løsning af selumordets gåde skulde rimeligvis $i$ mange tilfælde ledet os til retfærdige domme og et trøstigere häb om dem af vore medmennesker, hvis bortgang blev sådan. Og næst religionens formaning og trøst skulde vistnok intet være bedre skikket til at befæste de ulykkelige og svage imod selvmordets fristelser end klar kundskab om, hvad det er for særegne omstændigheder, som medføre sådanne særegne fristelser, så de ret itide kunde vabne sig imod den $i$ morket lurende fiende. I de fleste lande har man fundet, at selvmord bliver hyppigere og hyppigere. Der synes at ligge noget $i$ nutidens fremadskridende civilisation, som medfører dette."

\section{Oppsiktsvekkende?}

I en tilhørende fotnote forklares utviklingen nærmere:

"...Sand dannelse er sikkert ikke noget, som befordrer selvmord, men vel halvdannelse, der ikke sjelden medforer en stor disharmoni (uoverensstemmelse) mellom de fordringer, som den enkelte giør til verden, og de ydre forhold, hvor han $i$ virkeligheden nødes til at bevrge sig... Den blandt alle stander bemærkelige stræben at arbeide sig høiere op på de mange samfundsklassers trappestige er et eiendommelig marke ved vor tid...
Naturligvis står dygtigheden ikke alltid $i$ forhold til onsket; derfor bliver målet kun ufuldstændigt eller aldeles ikke opmået, deraf kommer da misfornøielse, utilfredshed med sin stilling, feilgreb $i$ valget af de midler som skulde fore til målet, livslede (en stemning, som ved aftagende religiøsitet sauner den sikreste modvagt) og endelig selvmord."

Fotnoten stammer fra boken "Versuch über den Menschen und die Entwicklung seiner Fähigkeiten" (s. 482) av den belgiske matematiker L. Quetelet, i tysk utgave av 1838 ved V. A. Riecke.

Den er spesielt interessant i forbindelse med at Durkheim ca. 60 år senere fremmet tilsvarende hypoteser om "anomi" som årsak til de økende selvmord (Guneriussen 1997). Sundt går deretter over til empiriske studier av selvmord $\mathrm{i}$ Norge i årene 1826-50.

\section{Empirien}

Mens tallet på mord og drap lå på ca. 200-266 pr. år i perioden 1826-31 (totalt 1400), ble det registrert disse tall for selvmord for følgende femårsperioder: (Tallene er det totale antallet selvmord $i$ gjeldende 5-årsperiode.)

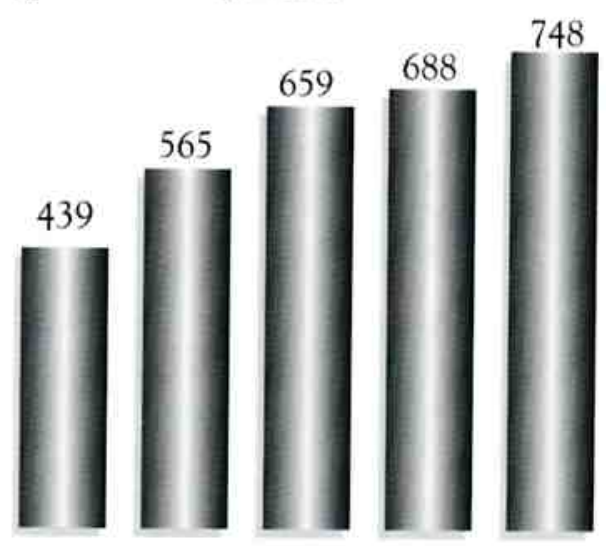

$\begin{array}{lllllll}1826-30 & 1831-35 & 1836-40 & 1841-45 & 1846-50\end{array}$

I følge Sundts beregninger innebærer dette at det pr. hundre tusen innbyggere ble begått 12 selvmord pr. år $\mathrm{i}$ årene 1826-5, 13 i årene 1831-40, og 14 pr. hundre tusen $i$ årene 1841-50.

Både $i$ absolutte tall og i rate ligger Christiania Stift langt foran landet for øvrig. Lavest lå til å begynne med Tromsø
Stift, men her $\emptyset \mathrm{kte}$ tallene i 1841-50. Til gjengjeld noterte Troms $ø$ seg for flest druknede på havet.

Når det gjelder metoder for selvmord, rangerer hengning foran drukning, skyting og "andre måter".

\section{Sammenligninger}

Sundt sammenligner sine funn med tilsvarende data fra Frankrike, Irland, England, Belgia, Baden, Sachsen og Danmark. Han finner både sammenfallende trekk og markante ulikheter, og siterer en rekke utenlandske kilder, bl. a. denne:

"Hvoraf kommer det", siger en preussisk læge Casper, som har helliget denne gienstand en omhyggelig undersøgelse, "Hvoraf kommer det, at $i$ England og også hos os (i Preussen) er strikken det sæedvanligste middel for aflivelse, medens $i$ Paris selvmorderen styrter sig ud fra broen eller fra vinduet eller jager sig en kugle gjennom panden? Må ikke iagttageren med interesse lægge mærke også til dette udtryck af nationaltemperamentet? Englænderen og tydskeren indeslutter sin kummer $i$ sit indre, og larmløst, $i$ det ensomme kammer, giøre ende på det glædeslose liv. Franskmanden vil endnu $i$ dette frygtelige øieblikk giøre sig bemærket; han vil ende med pomp; han vil give et skuespil til bedste for byen; naboerne skulle lobe sammen, begræde ham o.s.v.; derfor lader han sig se og hore, idet han går ud af verden."

Men Sundt tilføyer:

"Jeg mener nu ikke, at det skulde være ret med denne forfatter at sige, at det er en sådan bevidst lyst til at vække opmærksomhed, som leder den franske selvmorder $i$ valget av midlet; med dette sitat har jeg kun villet gjøre opmærksom på muligheden og sandsynligheden af, at det virkelig er sjelelige eiendommeligheder hos de forskjellige nationer, som fore til den her omhandlede forskjel." 


\section{Analyse}

Og videre:

"Av tallene for Frankrig og for Danmark ser man ligesom for Norge, at det forhold, som engang er det sæedvanlige $i$ et land, gientager sig så temmelig uforandret fra tid til anden, så forholdet må ansees for at være begrundet $i$ blivende, jevnt virkende årsager. Det er også mærkeligt at se, hvor disse forholde ere lige i Danmark og Norge. I begge lande er tilbvieligheden til at foretrekke hængming omtrent dobbelt så stor som i Frankrig, medens drukning og især skud anvendes langt mere $i$ det sidste land."

Og så, en konklusjon:

"Den store overensstemmelse mellom Danmark og Norge bestyrker den formodning, at det forhold, som viser valget av aflivelsesmåden hos de forskjellige nati-

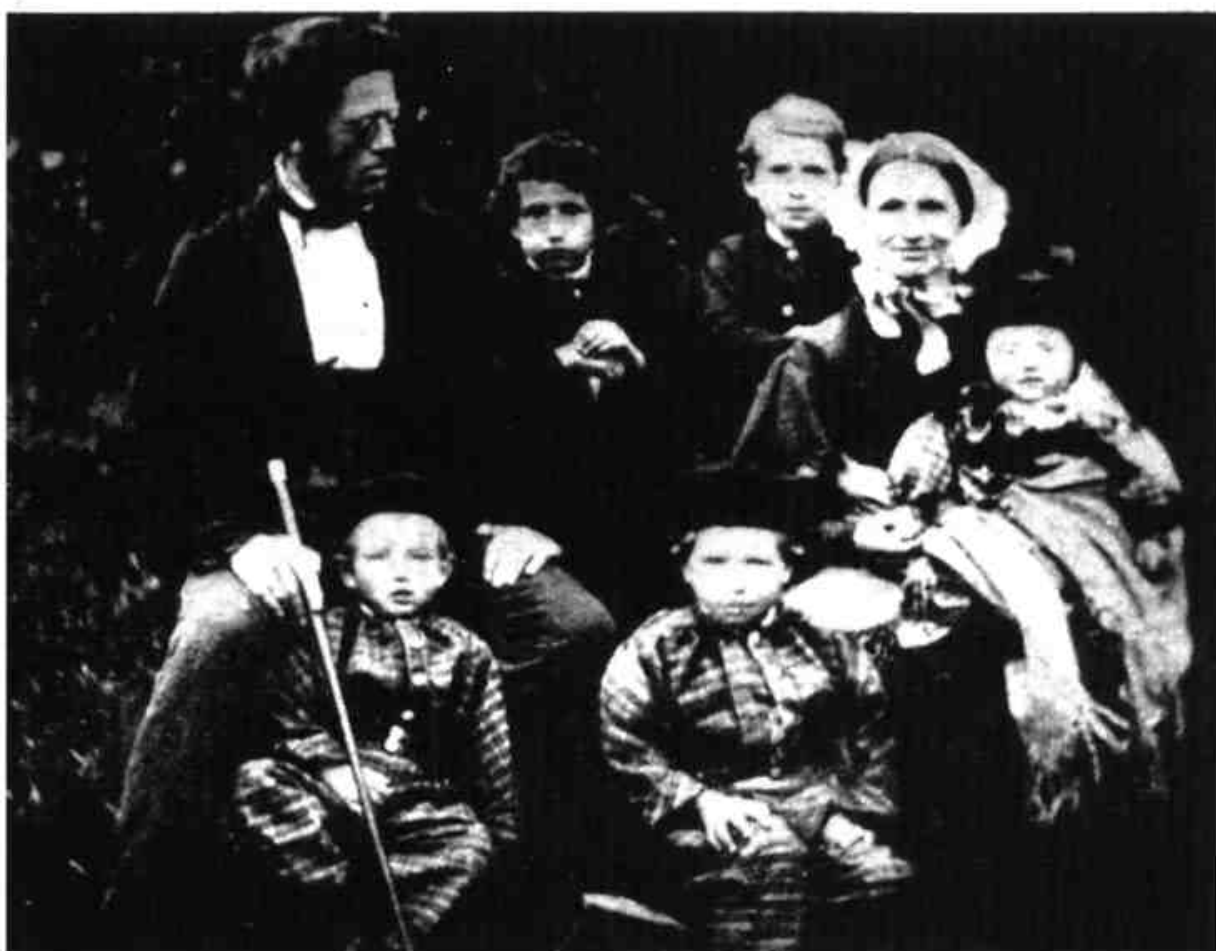

Nikoline Konradine og Eilert Sundt fikk syv barn hvorav fem sønner levde opp. Einar, den eldste, forretningsmann/økonom, grunnla forretningsbladet "Farmand" i 1891. Ole Johannes som ble ingeniør ved Carnegie Steel Works i Cleveland, Ohio, forsvant i 1914. Carl omkom i femårsalderen, ved en ulykke i 1864.

Mauritz ble forretningsmann i Buenos Aires, og døde i 1911. Lars bodde flere år $i$ Amerika, og ble senere lokalavisredaktør på Hadeland, og døde 90 år gammel $i$ 1952. Bildet er tatt $i 1863$.
Dersom man skulle stille spørsmål ved ett punkt i Sundts analyse, måtte det være hvorfor han ikke har delt sitt materiale etter kjønn (menn/kvinner) og alder. Disse data må antas å ha vært tilgjengelige, og de ville muliggjort enda dypere analyse. Ytterligere kan det som alltid også stilles spørsmål om "mørketall", eksempelvis i forbindelse med ulykker og mord/drap.

\section{Dagens tall}

Det kan være interessant å legge merke til at Sundts beregninger av antall selvmord pr. hundre tusen innbyggere er direkte sammenlignbare med dagens tall (Retterstøl 1996).

Mens Sundt fant gjennomsnittlig 12 selvmord pr. år pr. hundre tusen $\mathrm{i}$ årene 1826-35, finner Retterstøl det samme tall, 12 pr. hundre tusen i 1994 . Dette er antagelig oppsiktsvekkende.

\section{Sundts holdning til selvmord}

I pakt med vitenskapens beste tradisjoner var Sundt klar i sin tale:

"Ikke med en stavelse vil jeg istemme de philosophers tale, som forsvare selumordet og påstå, at mennesket har ret til med velberådt hu at skille sig af med livet, når verden går ham imod. Det må stå fast, at selvmord med velberådt hu er en uforsvarlig gjerning, og at der ligger ansvarlighed ved, når den alligevel begåes. Men...hvor ansvarlighed er tilstede, der hviler den ikke alene på den enkelte, som gjorde det, men også på samfundet...som skulle have omgivet ham med lutter gode og opmuntrende exempler, som skulde ha understottet hans svage sind med raid og formaning, som med ufortroden kjarlighed og utrættet tro skulde have hjulpet ham at skride imod fristelsen med Guds ords skjold.. 
Eilert Sundt var klar over kollektivets eller samfunnets betydning og ansvar, $\mathrm{og}$ foregrep på mange måter enkelte av de synspunkter Durkheim senere skulle komme med (Retterstøl 1995). Videre tok han avstand fra både dem som ensidig fordømte selvmord som en syndig handling, og dem som $i$ frihetens navn forfektet at selvmord er en menneskerett. Han presiserte sitt syn slik:

"I denne bog har jeg oftere gjort opmarksom på, hvorledes vindskibelighed og klogskab kan på mange måder forbedre et folks kår og derved forminske dødeligheden $i$ landet. Her er tanken fort videre. Jeg har henpeget på, at fromhedens og troens ånd må stå vagt og beskjærme menigheden og dens enkelte medlemmer mot fristelse og vildfarelse, mod synd og død. Og det er ikke blot selvmorderne, som må minde os herom...Selvmordernes skare er liden imod det lange tog af dem, som gå $i$ døden med bitter selvbebreidelse over de mange og fortsatte overtræedelser, hvormed de svakkede sin legems- og sjelskraft og derved forkortede sine dage. Vel må vi derfor gjentage den bon og lægge os dens formaning på sinde: "Herre, lær os så at tælle vore dage, at vi bekomme visdom $i$ hjertet!"

Dette skulle tyde på at Sundt ikke godtok noen deterministisk modell hvor "samfunnet" så å si automatisk kan tillegges skylden for alt som går galt. Tvertimot trodde han på menneskets frie vilje til å handle fornuftig - og etisk korrekt - dersom det blir tilført opplysning og kunnskap. Han betraktet åpenbart selvmordet innenfor en dualistisk modell - som et resultat av kampen mellom gode, byggende og onde, nedbrytende krefter i menneskesinnet.

Som i så mange andre sammenhenger blir folkeopplysning - ikke krangel og konflikt - hans svar på problemene, og det går som en rød tråd gjennom alt han har skrevet.

\section{Beskjeden livsførsel}

Bjørnstjerne Bjørnson kom i blant med tog fra Christiania og overnattet på prestegården for han neste dag tok "Skibladner" over Mjøsa til Lillehammer og fortsatte videre med karjol til Aulestad. For Sundt var det en selvfølge at også Bjømson satt ved kjøkkenbordet og spiste "vassgraut" til kvelds. Men denslags var nok ikke prestesønnen Bjørnson vant med. En gang satte dikteren skjeen hardt $i$ bordet, så alvorlig på sognepresten og sa: "Jeg håper det ikke er for

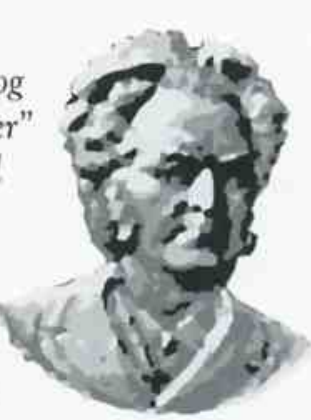
min skyld at det er så tarvelig her $i$ kveld".

Anekdoten er fortalt av forfatterens bestefar Lars Sundt (Eilert Sundts yngste sønn) som i en alder av ti-tolv år overhørte replikken.

\section{Arven etter Eilert Sundt}

Verdien av forskning beregnes ofte etter hvor fruktbar den er. Fører resultatene av ett prosjekt til kreative ideer om hypoteser for nye prosjekter? Ut fra dette perspektiv skulle man ha ventet at de utrolig omfattende resultater av Sundts 20-årige forskerinnsats ville ha skapt grunnlaget for en blomstrende samfunnsforskning i Norge. Men faget sosiologi var den gang ikke forankret i noe akademisk miljø.

Til tross for at Eilert Sundt - både i nasjonalt og internasjonalt perspektiv var en av sosiologiens grunnleggere, ble sosiologi universitetsfag i Norge så sent som 75 år etter hans død. De første lærere utgikk fra jus (som også Max Weber), og dette kom til å prege faget $\mathrm{i}$ mange år. lkke desto mindre er det mange forskere innen ulike fag i dag som er opptatt av de samme problemstillingene som Eilert Sundt reiste.

Mauritz Sundt Mortensen (f. 1936), er oldebarn av Eilert Sundt på morssiden, mangeårig journalist, Master of

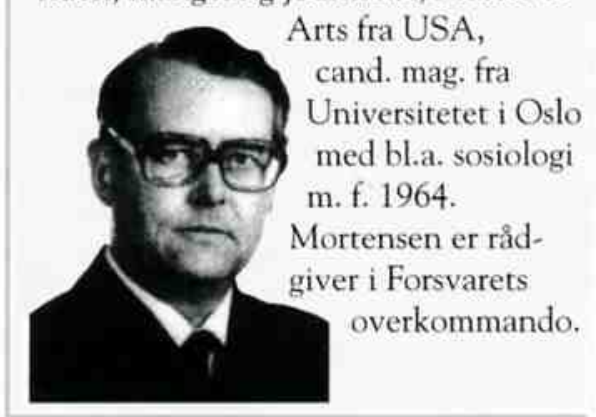

\section{Kilder:}

Christophersen, H. O. Eilert Sundt.

En dikter i kjennsgjerninger. Oslo: Gyldendal , 1962

Guneriussen, Willy. Émile Durkheims sosiologiske selvmordsteori. Nytt i suicidologi 1997; 3: 3-5

Retterstøl, Nils. Selvmord.

Oslo: Universitersforlaget, 1995.

Retterstøl, Nils. Selvmordsdata for Norge.

Nytt i suicidologi 1996; 1: 8-9

Sundt, Eilert. Verker i utvalg.

Under redaksjon av H. O. Christophersen,

Nils Christie, Kaare Petersen.

Oslo: Gyldendal, 1975.

1. Fante- eller landstrykerfolket i Norge, 1850 ,

2. Om dødeligheten i Norge/Om giftermâl i Norge, 1855 ,

3. Om Raros og omegn/Om Piperviken og Ruseløkkbakken/Harham,

4. Om sadelighetstilstanden i Norge, 1857 ,

5. Om adruelighedstilstanden i Norge, 1859 ,

6. Om bygningsskikken på landet i Norge, 1862 ,

7. På Havet,

8. Om husfliden i Norge, 1867.

9. Om renlighedsstellet i Norge, 1864.

10. Om huslivet i Norge, 1873.

11. Om fattigforholdene i Christiania.

Sundt, Rolf. Den vestlandske slekt. Sundt. Oslo 1954.
Vi takker
Gyldendal norsk forlag og forfatteren for utlan av bilder.

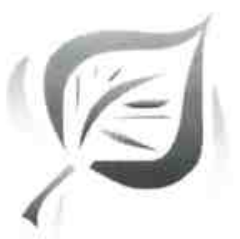

